\title{
Trends in industrial and environmental biotechnology research in Tanzania
}

\author{
Godliving Y. S. Mtui \\ Department of Molecular Biology and Biotechnology, University of Dar es Salaam P. O. Box 35179, Dar es Salaam, \\ Tanzania. E-mail: gmtui@hotmail.com. \\ Accepted 19 December, 2007
}

\begin{abstract}
This paper reviews the trends in industrial and environmental biotechnology research in Tanzania for the past 20 years. Researches on production of bio-energy, enzymes and organic acids are reviewed. Furthermore, researches related to wastewater treatment systems including water stabilization ponds and constructed wetlands are covered. Brief highlights are made on researches related to bioprospecting and molecular biology techniques used in identification of organisms. In critically reviewing the research done so far, an attempt is made to pinpoint significant research gaps in areas such as single cell protein, biomining, biocomposting and bioengineering. This paper, therefore, provides an overview of the renewable raw materials available in the developing countries and outlines the researches that have been done to convert them to bio-products, while reducing bio-wastes. The identified gaps will serve as guidance to scientists who are interested in doing research in untapped areas of biotechnology.
\end{abstract}

Key words: Biotechnology, bioenergy, biodegradation, biofiltration, biomining.

\section{INTRODUCTION}

Biotechnology offers industrial and environmental solutions. It uses living cells like moulds, yeasts or bacteria, as well as enzymes to produce value added products and services. Living cells can be used as they are or improved to work as "cell factories" to produce enzymes for industry. Living cells can also be used in production of antibiotics, vitamins, vaccines and proteins for medical use. Enzymes are a part of life and are present in all living beings. Whenever a substance is transformed into another, nature uses enzymes as biocatalyst to speed up the process. As an alternative to some chemical processes to make products, enzymes offer a biological route and often cleaner solution for industry. Ecoefficient, enzymes consume less water, raw materials and energy. Environmental impact is minimized while better products are offered at lower cost. Successful application of biotechnology integrates multiplicity of scientific disciplines including microbiology, biochemistry, genetics, molecular biology, chemistry and chemical engineering.

Substances made from renewable raw materials (or biomass) are another example of biotechnological products. Biomass like starch, cellulose, vegetable oils and agricultural waste are used in production of chemicals (green chemistry), biodegradable plastics, pesticides, new fibres and biofuels among other things. The processes manufacturing them use enzymes. Ethanol and methane, for example, which are renewable fuels produced by bioconversion of biomass, have great potential to replace fossil fuels. Biotechnology can: Reduce pollution and waste; decrease the use of energy, raw materials and water; lead to better quality food products; create new bio-based materials and biofuels from waste and provide an alternative to some chemical processes. Efficient utilization of natural bio-resources as a strategic base for sustainable industrial growth and to the development of effective bio-resource economy is paramount in achieving the interrelated economic, social and environmental objectives for sustainable human development.

In Tanzania, researches on biotechnologies related to agriculture and health have received more coverage than those related to industry and environment. This trend has led to misconception that biotechnology is synonymous to agricultural and medical biotechnology alone. In view of the importance of the subject, this paper reviews what has been done in Tanzania in terms of research on indu- 
strial and environmental biotechnology.

\section{ENERGY FROM BIOMASS BY ANAEROBIC SYSTEMS}

In East Africa, the agro-industrial residues form a major contribution to the pollution of air, soil and waterways, but at the same time, they constitute a large potential for production of bioenergy through anaerobic digestion as well as potential substrate for other biological fermentation processes. Generally, these residues are regarded as having no or very little value and different disposal methods are mainly a matter of getting rid of the waste. The generation of residues is very often concentrated on few large units, which makes the exploitation of these resources feasible in large-scale biogas systems. Typically, the units will have a potential of a daily methane generation of $1,000-20,000 \mathrm{~m}^{3}$ equivalent to a potential electricity production of $0.2-3.2 \mathrm{MW}$ (Jungersen et al., 1997). On average, Tanzania alone generates 148,000 tons of sisal decortications fibres residues annually. This amount could yield up to 22 million $\mathrm{m}^{3}$ of methane (Mshandete et al., 2006).

According to the surveys on the potential for biomass waste to alleviate energy problems in Tanzania through utilization of agro-industrial residues for anaerobic conversion into biogas and biodiesel, sisal industry, the largest producer of agro-industrial residues, has a potential to produce energy that could greatly supplement the current shortfall of hydropower generation (Kivaisi and Rubindamayugi, 1996). So far research on sisal waste has centered on pretreatment methods for processing of fibre fraction in order to increase the methane yield; evaluation of the requirement for nutrient addition; optimal reactor set-up and performance. Decortication has traditionally been done by the wet processing method, which consumes considerable quantities of water and produces large quantities of wastewater but recently, dry decortication methods that produce less waste products have been developed (Mshandete et al., 2006).

Pretreatment of lignocellulosic wastes prior to reactor operations has been shown to be effective in anaerobic digestion of bagasse, maize bran, coconut fibres, water hyacinth and sisal fibres. Reduction of the fibre sizes to less than $1 \mathrm{~mm}$ results to up to $76 \%$ increase in methane yield (Kivaisi and Eliapenda, 1994, 1995; Katima, 2001; Mshandete et al., 2006). For efficient anaerobic conversion, the researchers suggest that the sizes of fibres used should be reduced to $0.8 \mathrm{~mm}$. On the other hand, pretreatment by steam explosion is a physicochemical process to expose the substrates to enzymatic hydrolysis. Potato wastes have been steam-pretreated at 3.9 $\mathrm{MPa}$ pressure for $1.1 \mathrm{~min}$ to give hydrolytic products that are hydrolyzed by amylolytic microorganism such as Aspergillus awamori, and then fermented by Saccharomyces cerevisiae to bioethanol (Kobayashi et al., 1998).
The maximum ethanol concentration of $4.2 \mathrm{~g} / \mathrm{L}$ has been achieved in a batch culture process. Furthermore, chemical pretreatments have been shown to improve the yields of methane and bioethanol production. The effect of $\mathrm{NaOH}$ and $\mathrm{NH}_{4} \mathrm{OH}$ in significantly improving the production of volatile fatty acids (VFA) and methane have been demonstrated (Kivaisi and Eliapenda, 1994; Kivaisi, 2002; Nakamura and Mtui, 2003b). Coconut fibre and coffee hulls degradation are enhanced by up to 74 and $100 \%$, respectively, when alkali pretreatment precedes anaerobic digestion. On the other hand, acid pretreated municipal lignocellulosic wastes have been shown to perform better than non pretreated controls (Mtui and Nakamura, 2005). Microbial bioconversion of acidpretreated lignocellulose component produces up to $21 \%$ bioethanol. The studies show how poor economies like Tanzania could benefit by converting their poorly managed urban wastes, a chief source of urban pollution, into energy resources.

Co-digestion of lignocellulosics with other raw materials results to improved products. Co-digestion of sisal pulp and fish waste in a batch culture has been shown to improve the digestibility of the materials and biogas yield (Mshandete et al., 2004b). Compared to methane yields from sisal pulp and fish waste alone, an increase of up to $94 \%$ in the methane yield is achieved. In a parallel study, soybean curd residue supplement has been found to be very significant for enhancement of methane production from pretreated woody waste (Take et al., 2005). It is evident; therefore, that anaerobic co-digestion of lignocellulosic wastewater and sisal pulp is a viable alternative for recovering energy in the form of biogas at the same time abating environmental pollution.

Aerobic pretreatment of biomass prior to its anaerobic digestion is a recent initiative to improve the production of biofuels. Activated sludge mixed culture in batch bioreactors at $37^{\circ} \mathrm{C}$ enhances enzymatic activities of cellulase, amylase and xylanase through involvement of consortia of microorganisms present in the activated sludge (Mshandete et al., 2005b). $9 \mathrm{~h}$ of aerobic pretreatment of sisal pulp prior to anaerobic digestion demonstrates $26 \%$ higher methane yield compared to the sisal pulp without pre-treatment. Aerobic pretreatment with pure culture of Trichoderma reesei results to improved fibre digestibility and bioethanol production (Mtui and Nakamura, 2005). The studies suggest that aerobic-anaerobic systems offer a new dimension in the lignocellulosics biodegradation of wastes into value added bio-based products.

Research on anaerobic degradation of (ligno) cellulosic wastes by rumen microorganisms for enhanced production of methane and ethanol has shown a clear correlation between the lignin content of several wastes and natural materials and their degradability by rumen microorganisms (Huub et al., 1988). Materials with lignin contents higher than $25 \%$ seem not to be degraded within 72 h. At higher concentrations, p-coumaric acid 
strongly inhibits cellulose degradation and methane production in batch cultures. Generation of soluble ligninderived compounds during degradation of barley straw in an artificial rumen reactor indicates that rumen microorganisms are responsible for lignin degradation (Kivaisi et al., 1990).

Immobilization of biomass has a positive significant effect on yield. When acetogenic and methanogenic biomass are immobilized on polyurethane carrier, more than $50 \%$ methane yield is achieved (Rubindamayugi et al., $1989,1992)$. Recently, the performance of anaerobic packed-bed bioreactors treating leachate from potato waste has been evaluated. The reactor parked with sisal fibre decortication residues as biofilm carrier performs better than the conventional fluidized bed reactors (Mshandete et al., 2005a).

Bioreactor set-up and operation play a significant role in the success of anaerobic processes depending on the type of the substrates being used. A two-phase process involving connecting the acidogenic reactor in series to an up-flow anaerobic sludge blanket (UASB) methanogenic reactor leads to more efficient conversion of volatile fatty acids into biogas than when single reactors are used (Kivaisi et al., 1990, 1992; Kivaisi and Mtila, 1998). In terms of loading and recirculation of substrates in the reactor, it has been established that low organic loading rate (OLR) as well as slow recirculation flow rate significantly improve COD removal rate (Rubindamayugi et al., 1992; Mshandete et al., 2004a). The application of rumen microorganisms in batch and continuous culture experiments gave enhanced degradations of fibre fractions of maize bran and bagasse by 49 and $52 \%$, respectively, suggesting that efficient anaerobic conversion is achieved when artificial rumen reactor is used in combination with a high-rate methanogenic reactor (Kivaisi and Eliapenda, 1995). In a study on bioconversion of municipal solid waste (MSW), the assorted organic fractions have been tested for anaerobic conversion into biogas. Combining individual fractions with chicken manure at a ratio of 1:1 total solid (TS) increases the $\mathrm{N}$-content of the fractions by $16-133 \%$ and the volatile solid (VS) content of the fermenting substrate doubles, thereby substantially increasing methane production. Is seems that lignocellulosic fractions of MSW are suitable as feedstock for biogas digesters (Kivaisi and Mukisa, 2000). The effect of substrate concentration on biogas production shows that for water hyacinth, varying the substrate concentration between 5 - $30 \mathrm{~g} / \mathrm{l}$, achieves a maximum methane production of $72.53 \% \mathrm{v} / \mathrm{v}$ at substrate concentration of $25 \mathrm{~g} / 1$ (Katima, 2001).

So far, little has been done to apply the research findings in large-scale production systems. Tanzania is earmarked to be the first country in Africa to produce bioethanol from sugarcane (http://ippmedia.com). Trial production is expected to start in September 2007 under the Swedish firm, SECAB. The bioethanol will be used to run special Scania vehicles to be manufactured at Kiba- ha, Coast Region. Moreover, the United Nations Industrial Development Organization (UNIDO) in collaboration with Common Funds for Commodities (CFC), Katani Limited and Tanzania Sisal Board are financing another bio-energy plant at Hale Estate in Tanga region (http://www.unido.org/file-rd=49371). The project is expected to utilize sisal residues and cow dung starter to produce methane to be used to generate electricity while the by-products will be used as bio-fertilizer. The electricity produced is expected to be consumed by the Katani Limited industries while an initial surplus of $11 \mathrm{kV}$ is expected to be fed into the national grid. If realized, these are significant developments in putting the research results (on biomass for energy production) into practice for socioeconomic development and environmental protection.

\section{PRODUCTION OF ENZYMES OF ECONOMIC IMPORTANCE}

Research on production and purification of enzymes of economic importance has drawn a lot of interest. There have been efforts to isolate bacteria and screen fungi whose enzymes are of medicinal, industrial and environmental importance with the chief aim of isolating and characterizing them (Muruke et al., 1993, 1995, 1996; Akhmanova et al., 1998). Growth of Bacillus fastidiosus in a medium containing glycerol as a carbon source and urea as a nitrogen source leads to production of glycerol kinase, glycerol 3-phosphate, dehydrogenase, allantoinase, urease and carboligase under batch and continuous culture conditions. Considering that uricase is widely used in the determination of urate levels in blood and urine for treatment of gout and hyperuricaemia; and also for commercial formulations of hair colouring, an attempt has been made to purify uricase from $B$. fastidiosus in a two-step procedure with the aid of fastflow column chromatography (Muruke et al., 1996). In this way, high yields $(37 \%)$ of pure uricase with a specific activity of $78.3 \mathrm{U} / \mathrm{mg}$ are obtainable in a short time. The ease of culturing $B$. fastidiosus in modest carbon and nitrogen sources; feasible uricase purification and its high recovery rates, make this enzyme a potential product for commercial applications. In another study (Akhmanova et al., 1998), cytosolic enzymes with a mitochondrial ancestry from the anaerobic chytrid Piromyces sp. resulted in the isolation of cDNAs encoding malate dehydrogenase, aconitase and acetohydroxyacid reductoisomerases.

In recent years, there have been efforts to extract enzymes from Tanzanian wild mushroom species for industrial and environmental applications. Basidiomycetes fungi produce a wide range of extracellular cellulolytic and lignolytic enzymes capable of degrading lignocellulosic wastes and other recalcitrant organopollutants into soluble substances. These enzymes are secon- 
dary metabolic products, differing in chemical compositions and are often species-specific (Nakamura and Mtui, 2003a; Mtui and Nakamura, 2004). The three major classes of extracellular enzymes; manganese peroxidases (MnPs), lignin peroxidases (LiPs) and laccases (Lacs) are important in fungal degradation of lignocellulose. MnPs and LiPs are heme proteins while Lacs are copper-containing proteins. The potential applications of lignocellulosic enzymes from basidiomycetes fungi include biotransformation of lignocellulose biomas to feeds, fuels and chemicals; biobleaching of paper pulps; decolorizing and detoxifying kraft bleach effluents; and degradation of highly toxic environmental chemicals such as dioxins, polychlorinated biphenyls (PCBs), dichlorodiphenyltrichloroethane (DDT), azo dyes and polyaromatic hydrocarbons (Nakamura et al., 1997a, 1999; Mtui et al., 2000; Mtui and Nakamura, 2007). These fungi are therefore suitable for bioremediation of sites polluted with recalcitrant compounds and for upgrading lignocellulosic residues for animal feed.

Production of major lignocellulosic enzymes by Phanerochaete chrysosporium and Bjerkandera adusta in polyurethane foam (PUF) as a carrier of immobilized fungal mycelia in a culture medium enriched by $0.05 \%$ Tween $80,1 \mathrm{mM}$ veratryl alcohol and $1 \mathrm{mM} \mathrm{FeSO} \cdot 7 \mathrm{H}_{2} \mathrm{O}$ has been shown to significantly improve the production of LiP up to 2,700 units $/ \mathrm{ml}$ in both batch and continuous processes. A step change in incubation by lowering the temperature from 37 to $30^{\circ} \mathrm{C}$ has also been found to considerably increase LiP, MnP and Lac production at optimal $\mathrm{pH}$ of 4.5. Purified MnP, Lip and Lac isoenzymes have been shown to have relative molecular weights of 42,45 , and $67 \mathrm{kDA}$ and isoelectric points (pl) of 3.13 .5 and 4.5 respectively (Nakamura et al., 1997a, 1999; Mtui and Nakamura, 2002, 2007). Immobilization of purified lignocellulosic enzymes to facilitate their reuse, and scale-up studies for large scale industrial applications are the focus of ongoing research.

\section{PRODUCTION OF ORGANIC ACIDS AND OTHER COMPOUNDS OF ECONOMIC IMPORTANCE}

Biodegradation offers a dual advantage; Environmental cleanup and production of industrial products of economic importance. Chemical degradation of lignin-rich kraft pulp wastewater by ozonation in alkaline condition has been shown to produce muconic acid, maleic acid and oxalic acid that could be recovered and purified for industrial applications (Nakamura et al., 1997b; Mtui, 2001). Furthermore, production of significant amounts of lactic acid from sisal waste utilizing Lactobacillus $\mathrm{sp}$. isolate has been achieved in batch cultures (Muruke et al., 2006). In addition, $\beta$-1,3-glucan, an antineoplastic (antitumor or cytotoxic compound) has been produced from a basidiomycete Sparassis crispa in shake-flask liquid cultures (Kurosumi et al., 2006). The results of these bioconversion reports suggest that waste biomass are potential substrates for production of value-added compounds of economic importance.

\section{ENZYMATIC DEGRADATION OF ORGANIC POLLUTANTS}

In Tanzania, industrial discharges have led to serious environmental pollution problems especially in the urban centers, therefore, microbial and enzymatic waste treatments have become a topical area of research. Current reports have revealed that over $95 \%$ of Tanzanian saprophytic fungi possess lignolytic enzymes that degrade aromatic dyes, guaiacol, alpha-naphthol and pyrogallol (Mtui et al., 2003; Mtui and Nakamura, 2004, 2007). Moreover, such enzymes can reduce over $60 \%$ of lignin from animal feed such as rice straw and increase its relative crude protein content by more than $50 \%$. Tanzanian halotolerant fungi namely Flavodon flavus, Phlebia chrysocreas, Crepidotus variabilis, and Laetiporus sulphureus have been shown to degrade lignocellulose and recalcitrant organic pollutants (http://.www.wiomsa.org/research_reports/2006). Fungal enzymatic degradation of Dar es Salaam-based textile wastewater achieved a decolorization rate of $70 \%-100 \%$ using basidiomycetes fungi (Nilsson et al., 2006; Mtui and Nakamura, 2007). So far, studies show that such fungi are capable of mineralizing a variety of industrial effluents under both batch and continuous culture conditions.

\section{WASTE STABILIZATION PONDS}

Waste stabilization ponds (WSPs) are facultative ponds in which degradation of waste is brought about by a combination of aerobic, anaerobic and facultative bacteria. Three zones exist in the ponds; the surface zone where aerobic bacteria and algae exist symbiotically; intermediate zone which is partly aerobic and anaerobic where facultative bacteria are active; and anaerobic bottom zone where accumulated solids are decomposed by anaerobic bacteria. In Tanzania, WSPs are used mainly in urban centers for waste reduction and stabilization. The removal rates of biochemical oxygen demand (BOD) in facultative ponds in Dar es Salaam show that, on average, permissible organic loading rates (OLR) is $450 / \mathrm{ha} / \mathrm{d}$ (Mayo, 1996). Efficient removal of 99.96 and $99.98 \%$ total and faecal coliforms; COD and BOD reduction of 46 and $27 \%$; 32.6 and $32.4 \%$ decrease in conductivity and dissolved solids, respectively, have been reported (Mbwele et al., 2003). A pure strain of Aeromonas hydrophyla has been shown to be capable of taking up phosphorus in a medium supplemented by glucose, succinate and acetate in both aerobic and anaerobic conditions (Mbwele, 2006). It seems that the heterotrophic bacteria plays a crucial role in WSPs, there- 
fore, for enhanced performance, the primary ponds of WSPs should have maximum heterotrophic activity.

\section{CONSTRUCTED WETLANDS AS BIOTREATMENT SYSTEMS}

It is estimated that $90 \%$ of sewage in developing countries' urban centers are currently being discharged untreated into open water bodies. In Tanzania, pollution of rivers such as Karanga, Njoro and Rau in Moshi; Mirongo in Mwanza, Themi in Arusha and Msimbazi in Dar es Salaam is the cause of frequent disease outbreaks in lowland communities. Constructed wetlands (CWs) provide one of the conducive wastewater treatment systems. The potential for application of CWs and the current methods being used for wastewater treatment and reuse in developing countries have been reviewed by Kivaisi (2001). The horizontal subsurface flow (HSSF) constructed wetlands have been shown to have a steady state mean removal efficiencies of $80 \%$ suspended solids (SS), $66 \%$ COD, $91 \%$ fecal coliforms and $90 \%$ total coliforms achieved and maintained at a flow rate of 0.27 $\mathrm{m}^{3} / \mathrm{h}$ (Mashauri et al., 2000). Vetiver grass (Vetiveria zizanioides), common reeds (Phragmites mauritianus) and wetlands common grass (Typha macronata) are efficient biofilter macrophytes in the HSSF CWs where the soil (substrate) is supplemented by murram, granite and limestone (Mg'anya et al., 2000, Njau et al., 2003; Senzia et al., 2003). The studies show that constructed wetlands using macrophytes, if properly designed, operated and maintained, are a low cost and effective systems that can provide efficient means of upgrading the quality of secondary-treated wastewater to acceptable levels that can be discharged to the open environment.

\section{NITROGEN FIXATION, SULPHUR REDUCTION AND METHANOGENESIS IN MARINE SEDIMENTS}

Bioprospecting has led to discoveries of new strains and applications of known ones in nutrients cycling, nitrogen fixation, methanogenesis and sulfate reduction. Methanobacterium formicicum has shown nitrogen fixing abilities by utilizing molecular nitrogen as the sole nitrogen source (Magingo and Stumm, 1991). Methanogenesis and sulfate reduction are important processes responsible for the terminal electron removal during decomposition of organic matter in anaerobic environments. A novel obligately methylotrophic methanogenic bacteria, Methanosarcina semesiae MD1 (T), has been isolated from Tanzania's mangrove sediments and identified by analyzing the $16 \mathrm{~S}$ region of the rRNA; and sediments' organic matter contents, bacterial numbers, methane emission, sulphide concentration and redox potential profiles have been studied (Lyimo et al., 2000, 2002a, 2002b). The sediments are characterized as having high organic matter content and bacterial numbers. Sulphide concentration ranges from $1-25 \mathrm{mM}$ while a redox value varies from -150 to $-200 \mathrm{mV}$. The results demonstrate the importance of the anaerobic microbial activity in the mangrove sediments.

\section{MOLECULAR DIVERSITY AND IDENTIFICATION OF SPECIES OF ECONOMIC IMPORTANCE}

The suitability of using DNA techniques in molecular taxonomy has become a new area of study. In the determination of diversity and relatedness of species, edible mushrooms, Oudemansiella, Coprinus and Pleurotus have been identified using fruiting bodies as references. Polymerase chain reaction (PCR) and restriction fragment length polymorphism (RLFP) techniques are powerful tools in such analyses. The internally transcribed spacer region (ITS) and ribosomal RNA gene (rDNA) are amplified using ITS1 and ITS4 primers (Muruke et al., 2002; Martin et al., 2004). The method is fast, accurate, and provides a convenient means to explore basic questions about fungal diversity and relatedness among species.

\section{PRODUCTION OF EDIBLE MUSHROOMS}

Edible mushrooms are rich in proteins and vitamins, and have short regeneration time compared to higher plants. They can be produced industrially by cultivating spawn (mushroom seed material) using suitable substrates in special mushroom house/yard. Mushroom cultivation can be done on a wide range of weather conditions and therefore they offer an opportunity for food security and poverty alleviation especially for the impoverished rural population. Pleurotus flabellatus can be successfully cultivated on water hyacinth (Eichhornia crassipes) substrates shoots (Kivaisi et al., 2003), while Oudemansiella tanzanica nom. prov., has been successfully cultivated in lignocelulosic substrates such as sawdust, sisal waste and paddy straw supplemented with chicken manure (Magingo et al., 2004). Such studies have not only led to high productivity of a nutritious delicacy cultivated on cheap organic substrates, but they have also addressed the problem of solid waste utilization thereby contributing to alleviating the problem of environmental pollution.

\section{CARAGEENAN PRODUCTION FROM MARINE ALGAE}

Red algae are of considerable economic importance as they are used to produce bactericidal or bacteriostatic substances including amino acids, terpenoids, phlorotannins, acrylic acid, phenolic compounds, steroids, haloge- 
nated ketones and alkanes, cyclic polysulphides and fatty acids (Mtolera and Semesi, 1996). They are also widely used for agar production; can be utilized as human food or as feed for marine fauna; in wastewater treatment through nutrient removal and as biomass for energy generation. Eucheuma denticulatum has been studied by Semesi et al. (2001) while Buriyo et al. $(2003,2004)$ and Mtolera and Buriyo (2004) have described nine species of Gracilari and Hypnea in Tanzania. Carrageenan yield of up to $56 \%$ (dry weight) has been achieved.

\section{GAPS IN BIOTECHNOLOGY RESEARCH IN TANZANIA}

Tanzania is endowed with rich mineral deposits. Biotechnology offers a feasible way of extracting the metals from their ores by utilizing oxidative microorganisms such as Thiobacillus ferooxidans and Leptospirillum ferrooxidans in acidic media and Gallionella sp. and Leptotrix sp. in non-acidic media. This process, namely biomining, has so far received little attention by Tanzanian researchers. It is suggested that a multidisciplinary research involving biologists, geologists and soil engineers should be conducted in order to come up with biologically mediated process to extract metals by native microorganisms. This approach is more economical and environmentally friendly than conventional mining processes.

Single cell protein (SCP) refers to cultivation of unicellular or sometimes multicellular organisms as source of food. Except for the aforementioned few research reports on edible mushroom cultivation (Kivaisi et al., 2003 and Magingo et al., 2004), there has been little or no research done on culturing and utilization of edible microorganisms as source of food. Aflatoxin-free organisms such as algae (Clorella sp., Scenedesmus sp.); yeasts: (Candida guilliemondii, C. utilis, C. lipolytica, and C. tropicalis, Debaryomyces kloeckeri, Candida famata, C. methanosorbosa, Pichia sp., Kluyveromyces fragilis, Hensenula polymorpha, Rhodotorula sp., and Saccharomyces sp.; and bacteria (Baccilus sp., Acinetobacter calcoaceticus, Cellulomonas sp., Nocardia sp., Methylomonas sp., Aeromonas hydrophilla, Alcaligenes eutrophus, Spirulina maxima and Rhodopseudomonas sp.) could be used as sources of food (James, 2000). The short generation time of SCP provides a rapid mass increase and high productivity. Furthermore, microorganisms can be easily modified genetically to produce cells that bring about desirable results. In addition, production of SCP can be based on raw materials readily available in large quantities; and cultivation can be carried out in both batch and continuous cultures systems which are normally independent of climatic changes.

Currently, success of Tanzania's (and other developing countries') agriculture relies heavily on artificial chemical fertilizers such as sulphate of ammonia (SA), NPK and urea. These chemicals are not only expensive, but also they result to degraded soils. Biocomposting as a potential technology for bioconversion of agro-industrial wastes is another area of study which has so far received little or no attention at all. Aerobic and anaerobic composting are affordable and environmentally friendly processes of improving mineral content, structure and texture of soils. The term vermicomposting or vermiculture refers to the use of earthworms for composting organic residues. Earthworms can consume practically all kinds of organic matter and their excreta are rich in nitrate, available forms of $\mathrm{P}, \mathrm{K}, \mathrm{Ca}$ and $\mathrm{Mg}$. Biocomposting, including vermicomposting should therefore be researched as a potential source of biofertlizer. With the favourable tropical climate, worms could also be mass produced and sold to farmers for vermiculture (and feed for fish in aquaculture) as a source of income. With more than $80 \%$ Tanzania's population depending on pit latrines (Mashauri et al., 2000), biolatrine research should also be considered to be key area of study for enhanced biocomposting.

There has been very limited research on biotechnological methods to improve animal feed such as inoculation of straw with lignocellulosic fungi to delignify and improve the nitrogen content of the latter (Mtui et al., 2003). With its vast population of livestock and unreliable weather conditions that leads to occasional feed deficiencies, developing countries need to put more emphasis on animal feed research related to enrichment of nutrients including vitamins and mineral elements.

Though controversial in some parts of the world, bioengineering research should not be set aside. Tanzania has just trained experts and introduced molecular biology units in its academic institutions. While adhering to already formulated biosafety guidelines, research on genetically engineering stains such as recombinant yeast for improved processes and products; recombinant bacteria as a source of chemotherapies; and novel degradative organisms or enzymes for biodegradation of recalcitrant wastes, including plastics, should be the focus of research for molecular biologists.

\section{CONCLUSION}

Research on industrial and environmental biotechnology in Tanzania has come of age. Substantial work has been done in the field of industrial biotechnology in areas of production of methane and bioethanol which could be used to avert the energy crisis facing the developing countries. Enzymatic degradation of waste with the concomitant bioremediation of polluted environments; microbial waste stabilization, phytoremediation through biofiltration in constructed wetlands, production of useful chemicals such lactic acid and oxalic acid are some of the researches that have already been done in the area of environmental biotechnology. More efforts should be directed to areas such as biomining, which, if done, could 
contribute to developing the African countries' least exploited mineral resources; and single cell proteins research that could get the region out of malnutrition and poverty woes. Biocomposting for agricultural development, improvement of animal feeds and genetic engineering of economically important strains have been singled out as research areas that have been underexplored and need researchers' attention. This work attempted to put together most of the biotechnological researches that have been done in Tanzania (or elsewhere by Tanzanians together with their collaborators) over a period of 20 years for ease of reference and enhancement of closer research collaborations.

\section{ACKNOWLEDGEMENTS}

Sincere gratitude goes to Sida/SAREC/ISP for financially supporting my stay at Uppsala University, Sweden, as a Guest Researcher where I got an opportunity to write this review. The University of Dar es Salaam, Tanzania, is gratefully acknowledged for granting leave of absence from my workplace. Dr. Anthony Mshandete is thanked for his constructive comments on the manuscript. My family is appreciated for their moral support and for enduring my absence.

\section{REFERENCES}

Akhmanova A, Voncken FGJ, Harhangi H, Hosea KM, Vogels GD Hackstein JH (1998). Cytosolic enzymes with a mitochondrial ancestry from the anaerobic chytrid Piromyces sp. E2. Mol. Microbiol. 30(5): 1017-1027.

Buriyo AS, Kivaisi AK (2003). Standing stock, agar yield and properties of Gracilaria salicornia harvested along the Tanzanian coast. Western Indian Ocean J. Mar. Sci., 2(2): 171-178.

Buriyo AS, Oliveira EC, Mtolera MSP, Kivaisi AK (2004). Taxonomic challenges and distribution of gracilarioid Algae in Tanzania. West. Indian Ocean J. Mar. Sci. 3(2): 135-141.

Huub JM, Op den Camp HJM, Verhagen FJ, Kivaisi AK, de Windt FE (1988). Effects of lignin on the anaerobic degradation of (ligno) cellulosic wastes by rumen microorganisms. Environ. Microbiol. 29(4): 404-412.

James MJ (2000). Modern Food Microbiology. $6^{\text {th }}$ Ed., p. 422.

Jungersen G, Kivaisi A, Rubindamayugi M (1997). Biogas- Bioenergy Potential in East Africa. Proc. Workshop on Bioenergy from Sisal Wastes. Silver Sands, Dar es Salaam, pp. 22-23.

Katima JHY (2001). Production of biogas from water hyacinth: Effect of substrate concentration, particle size and incubation period. Tanz. J. Sci. 27: 107-119.

Kivaisi AK (2001). The potential for constructed wetlands for wastewater treatment and reuse in developing countries: A review. Ecol. Eng. 16(4): 545-560.

Kivaisi AK (2002). Pretreatment of robusta coffee hulls and co-digestion with cow-dung for enhanced anaerobic digestion. Tanz. J. Sci. 28(2): 1-10.

Kivaisi AK, Eliapenda S (1994). Pretreatment of bagasse and coconut fibres for enhanced anaerobic degradation by rumen microorganisms. Renew. Energy 5: 5-8.

Kivaisi AK, Eliapenda S (1995). Application of rumen microorganisms for enhanced anaerobic degradation of bagasse and maize bran. Biomass and Bioenergy. 8(1): 45-50.

Kivaisi AK, Gijzen HJ, Op den Camp HJM, Vogels GD (1992). Conversion of cereal residues into biogas in a rumen-derived process. World J. Microbial. Biotechnol. 8(4): 428-433.
Kivaisi AK, Huub JM, Lubberding HJ, Boon JJ, Vogels, GD (1990). Generation of soluble lignin-derived compounds during degradation of barley straw in an artificial rumen reactor. Appl. Microbiol. Biotechnol.. 33(1): 93-98.

Kivaisi AK, Magingo FSS, Mamiro B (2003). Performance of Pleurotus flabellatus on water hyacinth (Eichhornia crassipes) shoots at two different temperature and relative humidity regimes. Tanz. J. Sci. 29(2): 11-18.

Kivaisi AK, Mtila M (1998). Production of biogas from water hyacinth (Eichhornia crassipes) in a two-stage bioreactor. World J. Microbiol. Biotechnol. 14(1): 125-131.

Kivaisi AK, Mukisa J (2000). Composition and Anaerobic Digestion of Single and Combined Organic Fractions of Municipal Solid Waste of Dar es Salaam. Tanz. J. Sci. 26: 67-78.

Kivaisi AK, Rubindamayugi MST (1996). The potential of Agro-industrial residues for production of biogas and electricity. Renew. Energy (14): 917-921.

Kobayashi F, Sawada T, Nakamura Y, Mtui GYS, Ushiyama T (1998). Saccharification and alcohol fermentation in starch solution of steamexploded potato wastes. Appl. Biochem. Bioeng. 69: 43-55.

Kurosumi A, Kobayashi F, Mtui G, Nakamura Y (2006). Development of optimal culture method of Sparassis crispa mycelia and new extraction method of antineoplastic constituent. Biochemical Eng. J. 30: 109-113.

Lyimo TJ, Pol A, Op den Camp HJM (2002a). Methane emission, sulphide concentration and redox potential profiles in Mtoni mangrove sediment, Tanzania. Western Indian Ocean J. Marine Sci. 1(1): 71 80.

Lyimo TJ, Pol A, Op den Camp HJM (2002b). Sulfate reduction and methanogenesis in sediments of Mtoni mangrove forest, Tanzania. Ambio 31(7): 614-616.

Lyimo TJ, Pol A, Op den Camp, HJM, Harhangi HR, Vogels (2000). Methanosarcina semesiae sp. nov., a dimethylsulfide-utilizing methanogen from mangrove sediment. J. System. Evol. Microbiol. 50: 171-178.

Magingo FS, Ndekya MO, Kivaisi AK (2004). Cultivation of Oudemansiella tanzanica nom. prov. on agricultural solid wastes in Tanzania. Mycologia 96(2): 197-204.

Magingo FSS, Stumm CK (1991). Nitrogen fixation by Methanobacterium formicicum. FEMS Microbiol. Lett. 81(3): 273-277.

Martin P, Muruke M, Hosea, K, Kivaisi A, Zerwas N, Bauerle C (2004). $A$ rapid PCR-RFLP method for monitoring genetic variation among commercial mushroom species. Biochem. Mol. Biol. Educ 32 (6): 390-394.

Mashauri DA, Malungu DMM, Abdulhussein BS (2000). Constructed wetland at University of Dar es Salaaam. Water Res. 34(4): 11351144.

Mayo AW (1996). BOD removal in facultative ponds: Experience in Tanzania. Water Sci. Technol. 34(11): 107-117.

Mbwele L, Rubindamayugi M, Kivaisi A, Dalhammar G (2003). Performance of a small wastewater stabilisation pond system in tropical climate in Dar es Salaam, Tanzania. Water Sci. Technol. 48(11): 187-191.

Mbwele LA (2006). Microbial phosphorus removal in waste stabilization ponds wastewater treatment systems. A Licentiale Thesis. Royal Insti. of Technol., Stockholm, Sweden, p. 42.

Mg'anya SE, Njau KN, Katima JHY (2000). The Suitability of murram and mimestone for preatment of wastewater in subsurface flow constructed wetlands. Proc. Regional Conf. on Appl. of Wetland Systems in Water Pollution Control. University of Dar-es-Salaam, pp. 1-12.

Mshandete A, Björnsson L, Kivaisi AK, Rubindamayugi MST, Mattiasson B (2005a). Performance of a fixed bed anaerobic digester filled with sisal fibres for biogas production from semi solid sisal pulp waste. Tanz. J. Sci. 31(2): 41-52.

Mshandete A, Björnsson L, Kivaisi AK, Rubindamayugi MST, Mattiasson, B (2006). Effect of particle size on biogas yield from sisal fibre waste. Renew. Energy 31(14): 2385-2392.

Mshandete A, Björnsson L, Kivaisi AK, Rubindamayugi S, Mattiasson B (2005b). Enhancement of anaerobic batch digestion of sisal pulp waste by mesophilic aerobic pre-treatment. Water Res. 39(8): 15691575. 
Mshandete A, Kivaisi AK, Rubindamayugi M, Mattiasson B (2004b). Anaerobic batch co-digestion of sisal pulp and fish wastes. Bioresour. Technol. 95(1): 19-24.

Mshandete A, Murto M, Kivaisi AK, Rubindamayugi MS, Mattiasson B (2004a). Influence of recirculation flow rate on the performance of anaerobic packed-bed bioreactors treating potato-waste leachate. Environ. Technol. 25(8): 929-936.

Mtolera MSP, Buriyo AS (2004). Studies on Tanzanian hypneaceae: Seasonal variation in content and quality of Kappa-Carrageenan from Hypnea musciformis. Western Indian Ocean J. Mar. Sci. 3 (1): 43-49.

Mtolera MSP, Semesi AK (1996). Antimicrobial activity of extracts from six green algae from Tanzania. Proc. Current Trends in Marine Botanical Research in East Africa, pp. 211-217.

Mtui G, Nakamura Y (2004). Lignin-degrading enzymes from mycelial cultures of basidiomycetes fungi. J. Chem. Eng. Jpn. 37(1): 113-118.

Mtui G, Nakamura Y (2005). Bioconversion of lignocellulosic waste from selected dumping sites in Dar es Salaam, Tanzania. Biodegradation 16(6): 493-499.

Mtui G, Nakamura Y (2007). Characterization of lignocellulosic enzymes from white-rot fungus Phlebia crysocreas isolated from a marine habitat. J. Eng. Appl. Sci. 2(10): 1501-1508.

Mtui G, NakamuraY (2002). Continuous production of lignin-degrading enzymes by Bjerkandera adusta immobilized on polyurethane foam. Biotechnol. Lett. 24(21): 1743-1747.

Mtui GYS (2001). Combined chemical and biological treatment of recalcitrant wastewater: A case study on kraft pulp wastewater. Tanz. J. Sci. 27A: 79-91.

Mtui GYS, Kivaisi AK, Masalu R (2003). Production of lignin-degrading enzymes from native Tanzanian mushrooms. Proc. of 2 nd International Conference on Medicinal Mushrooms. Pattaya, Thailand, pp. 163-169.

Mtui GYS, Nakamura Y, Sawada T (2000). Enzyme production and characteristics of lignin degradation in white-rot fungi. Proc. Ann. Conf. Biochem. Eng. and Biotechnol. Hokkaido, Japan. 1129: 274275.

Muruke MHS, Hosea KM, Palangyo A, Heijthuijsen JHFG (2006). Production of lactic acid from waste sisal stems using a Lactobacillus isolate. Discov. Innov. 18(1): 1-5.

Muruke MHS, Kivaisi AK, Magingo FSS, Danell E (2002). Identification of mushroom mycelia using DNA techniques. Tanz. J. Sci. 28(1): 115-128.

Muruke MHS, Op den Camp HJM, Semesi AK, van der Drift, C (1995). The level of enzymes involved in the allantoin metabolism of Bacillus fastidiosus grown under different conditions. Curr. Microbiol. 30(1): 45-47.

Muruke MHS, Op den Camp HJM, van der Drift C (1993). Novel nitrogen sources for growth of Bacillus fastidiosus and their effect on the activity of NADP-dependent glutamate dehydrogenase. FEMS Microbiol. Lett. 114(2): 195-199.

Muruke MHS, Op den Camp HJM, van der Drift C (1996). Rapid purification of uricase from Bacillus fastidiosus Biotechnol. Tech. 10(9): 709-712.

Nakamura Y, Mtui G (2003a). Biodegradation of endocrine disrupting phenolic compounds using laccase and activated sludge Treatment. Biotechnol. Bioprocess Eng. 8 (5): 294-298.
Nakamura Y, Mtui G (2003b). Anaerobic fermentation of woody biomass treated by various methods. Biotechnol. Bioprocess Eng. 8(3): 179-182.

Nakamura Y, Mtui GYS, Sawada T, Kuwahara M (1999). Lignindegrading enzyme production from Bjerkandera adusta on polyurethane foam. J. Biosci. Bioeng. 88(1): 41-47.

Nakamura Y, Sawada T, Kobayashi F, Mtui G (1997b). Microbial treatment of kraftpulp wastewater pretreated with ozone. Water Sci. Technol. 35(2): 277-282.

Nakamura Y, Sawada T, Mtui GYS, Kobayashi F, Kuwahara M, Ito, H (1997a). Lignin Peroxidase Production by Phanerochaete chrysosporium Immobilized on Polyurethane Foam. J. Chem. Eng. Jpn 30(1): 1-6.

Nilsson I, Moller A, Mattiasson B, Rubindamayugi MST, Welander U (2006). Decolorization of synthetic and real textile wastewater by the use of white-rot fungi. Enzyme Microb. Technol. 38(1-2): 94-100.

Njau KN, Mlay HM (2003). Wastewater treatment and other research initiatives with vetiver grass. Proc. of the Intl. Conf. on Vetiver grass. Mexico. pp. 25-31.

Rubindamayugi MST, Broeders P, op den Camp HJM, Lubberding HJ, Vogels GD (1989). Studies on the optimization of immobilizing acetogenic and methanogenic biomass on polyurethane carrier. Med. Fac. Landbouw. Rijksuniv. Gent. 53(4b): 1957-1961.

Rubindamayugi MST, op den Camp HJM, Lubberding HJ, Gijzen HJ, Vogels GD (1992). Influence of hydraulic retention time on start-up and process stability of polyurethane carrier reactors. Water Sci. Technol. 25(1): 99-106.

Semesi AK, Buriyo AS, Mtolera MSP (2001). The effect of seasons on yield and quality of carrageenan from Tanzanian red alga Eucheuma denticulatum (Gigartinales, Rhodophyta). S. Afr. J. Bot. 67(3): 488491.

Senzia MA, Mashauri DA, Mayo, AW (2003). Suitability of constructed wetlands and waste stabilisation ponds in wastewater treatment: nitrogen transformation and removal [Phys. Chem. Earth $(A, B, C)]$. 28(20-27): 1117-1124

Take H, Mtui G, Kobayashi F, Nakamura Y (2005). Additive effect of soybean curd residue, Okara, for enhancement of methane production from pretreated woody waste. J. Food Technol. 3(4): 535537. 